\section{Ocean Modelling}

www.elsevier.com/locate/omodol

\title{
Comparing modeled streamfunction, heat and freshwater content in the Arctic Ocean
}

\author{
N. Steiner ${ }^{\mathrm{a}, *}$, G. Holloway ${ }^{\mathrm{a}}$, R. Gerdes ${ }^{\mathrm{d}}$, S. Häkkinen ${ }^{\mathrm{b}}, \mathrm{D}$. Holland ${ }^{\mathrm{c}}$, \\ M. Karcher ${ }^{\text {d }}$, F. Kauker ${ }^{\text {d, W. Maslowski }}{ }^{\text {e }}$, A. Proshutinsky ${ }^{\text {f }}$, M. Steele ${ }^{\text {g, }}$, \\ J. Zhang $\mathrm{g}$ \\ ${ }^{a}$ Institute of Ocean Sciences, 9860 West Saanich Road, Sidney, BC, Canada V8L4B2 \\ ${ }^{\mathrm{b}}$ NASA/Goddard Space Flight Center, Greenbelt, MD, USA \\ ${ }^{\mathrm{c}}$ New York University, USA \\ d AWI, Bremerhaven, Germany \\ e Naval Postgraduated School, Monterey, CA, USA \\ ${ }^{\mathrm{f}}$ Woods Hole Oceanographic Institution, USA \\ ${ }^{\mathrm{g}}$ University of Washington, Seattle, USA
}

\begin{abstract}
Within the framework of the Arctic Ocean Model Intercomparison Project results from several coupled sea ice-ocean models are compared in order to investigate vertically integrated properties of the Arctic Ocean. Annual means and seasonal ranges of streamfunction, freshwater and heat content are shown. For streamfunction the entire water column is integrated. For heat and freshwater content integration is over the upper $1000 \mathrm{~m}$. The study represents a step toward identifying differences among model approaches and will serve as a base for upcoming studies where all models will be executed with common forcing. In this first stage only readily available outputs are compared, while forcing as well as numerical parameterizations differ.

The intercomparison shows streamfunctions differing in pattern and by several Sverdrups in magnitude. Differences occur as well for the seasonal range, where streamfunction is subject to large variability.

Annual mean heat content, referenced to $0{ }^{\circ} \mathrm{C}$, in the Canada Basin varies from -3.5 to $+1.8 \mathrm{GJ} \mathrm{m}^{-2}$ among the models, representing both colder and warmer solutions compared to the climatology. Seasonal range is highest in regions with seasonal or no ice cover.

Corresponding freshwater content, referenced to $34.8 \mathrm{ppt}$, shows differences most obviously in the Beaufort Sea and Canada Basin where maximum values vary between 6 and $24 \mathrm{~m}$ for the individual models. Maxima in the seasonal range are related to river inflow.

In the current stage of the project, applied windstress contributes significantly to the differences. However differences due to model resolutions and model parameterizations can already be detected.

(C) 2003 Elsevier Ltd. All rights reserved.
\end{abstract}

\footnotetext{
${ }^{*}$ Corresponding author. Tel.: +1-250-3636550; fax: +1-250-4724683.

E-mail address: steinern@pac.dfo-mpo.gc.ca (N. Steiner).
} 
Keywords: Arctic Ocean; Freshwater; Heat content; Streamfunction; Model intercomparison

\section{Introduction}

Due to the feedbacks in the ocean-sea ice system the Arctic Ocean is supposed to be an early indicator of climate change (e.g. Manabe et al., 1991; Rind et al., 1995). Large changes in the hydrography and in sea ice conditions have been observed in previous decades (e.g. Rothrock et al., 1999; Morison et al., 1998). As reservoir of fresh water in form of sea ice and in the form of low salinity water of the Arctic halocline, it bears the potential of influencing the global thermohaline circulation through fresh water export to the deep water formation sites in the northern North Atlantic. The apparently strong interannual variability and the difficulties in collecting observations of oceanic properties in the Arctic gives special importance to model simulations of Arctic developments.

Assessment of interannual to decadal variability and the response to long term climate change require different modeling approaches. The former is addressed with regional ocean-sea ice models that are typically forced with atmospheric data from reanalysis projects. The latter is the domain of coupled global climate models. The representation of the Arctic ocean-sea ice system in typical climate models is rather crude due to coarse resolution and the customary zonal filtering of prognostic variables to avoid time step limitations caused by the converging meridians. Regional ocean-sea ice models can help to improve the representation of the Arctic in climate models by indicating better representations of ocean-sea ice processes. This is the primary aim of the Arctic Ocean Model Intercomparison Project (AOMIP Proshutinsky et al., 2001). The present study, as part of AOMIP, intercompares output from six coupled sea ice-ocean models that cover the Arctic Ocean (e.g., Nazarenko et al., 1998; Häkkinen, 1999; Maslowski et al., 2000; Zhang et al., 2000; Holland, 2001; Karcher et al., in press). These models aim at the most realistic representation of the ocean-ice system under the individual constraints of computational resources and quality and accessibility of initial and forcing data. All models are based on the primitive equations. They differ, however, in resolution and parameterization of subgrid scale processes. They also differ in initial conditions, spin-up procedure and details of the atmospheric forcing. The three main choices of vertical coordinate system are represented among these models. Most of the models use geopotential coordinate surfaces, however, Häkkinen (1999) uses terrainfollowing $\sigma$-coordinates and Holland (2001) uses isopycnic coordinates. These three basic choices were the focus of the Atlantic model comparison in the European Union project DYNAMO (DYNAMO group, 1999; Willebrand et al., 2001). The DYNAMO project found that considerable differences in model results could be due to the choice of the vertical coordinate system. The bandwidth of results from the above Arctic models is an indicator of the overall uncertainty of Arctic Ocean models due to basic model design (coordinate system, resolution, numerical algorithms), initial conditions, parameterizations, and boundary conditions. This might seem an excessive array of possible sources for differences between models. However, all these choices are arguably reasonable and represent the state of the art in Arctic Ocean modeling. 
While we are content in this study with documenting the current range of model results for the Arctic ocean-sea ice system, AOMIP was initiated to systematically compare regional Arctic Ocean models and formulate recommendations to the climate modeling community. In AOMIP's first phase, already existing output is compared where forcing as well as physical and numerical parameters are not standard. Subsequently, all models will execute a spin-up experiment under variable forcing with common specifications (http://fish.cims.nyu.edu/project_aomip/overview. html).

This study presents results from the first stage of the project. Also from this first stage, the studies of Steele et al. (2001a) and Proshutinsky et al. (2001) discussed surface salinity and surface elevation, respectively. The present appraisal addresses vertically integrated properties as volume transport streamfunction, integrated from top to bottom, and heat and freshwater content, integrated over the top $1000 \mathrm{~m}$ of the water column.

At this stage of the project we begin to identify differences, address possible causes and open a discussion extending to upcoming AOMIP phases. In the following sections the participating models are introduced and their representations of streamfunction, heat and freshwater content are shown. Possible origins of their differences will be discussed.

\section{Model and data description}

Table 1 gives a summary over parameterizations applied in the individual ocean models. All participating models have a dynamic-thermodynamic sea ice component coupled to the ocean and cover the entire Arctic Ocean. Sea ice model parameterizations are summarized in Table 2. Temperature profiles for ice and snow (if applicable) are assumed to be linear, defined by the corresponding top and bottom temperature. None of the models include a tidal parameterization. All models apply bulk parameterizations for heat, moisture and momentum exchanges, however exchange coefficients are not common at this stage. For the coordinated spin-up experiment common coefficients and formulations will be applied as specified on the AOMIP webpage.

The different model results are presented on a common domain (Fig. 1) to simplify the intercomparison. Tables 3 and 4 provide detailed information on the atmospheric forcing. Data from monthly as well as from daily climatologies is applied and the modeled timeperiods differ as well as the source of the forcing. Depending on availability, results from climatological mean forcing (denoted with -c) as well as results from timeseries runs (year 1998, denoted with -98) are presented. Climatological forcing has been averaged over the given time periods (Table 3), where AWI-c, IOS-c, NYU-c have been integrated for 30 years and GSFC-c for 15 years. The presented results are from the last year of integration.

The variables evaluated in the current study are:

(1) Volume transport streamfunction (hereafter simply streamfunction), $\Psi$, in $\mathrm{Sv}\left(1 \mathrm{~Sv}=10^{6}\right.$ $\mathrm{m}^{3} \mathrm{~s}^{-1}$ ), integrated from top to bottom, is defined by

$$
\mathbf{k} \times \nabla \Psi=\int_{0}^{\text {bottom }} \mathbf{u d} z
$$

with velocity $\mathbf{u}$ and vertical unit vector $\mathbf{k}$. 
Table 1

Ocean model specifications: AOMIP topography refers to the merged IBCAO/ETOPO5 dataset (Holland, 2000)

\begin{tabular}{|c|c|c|c|c|c|c|}
\hline & AWI & GSFC & IOS & NPS & NYU & UW \\
\hline $\begin{array}{l}\text { Horizontal } \\
\text { Coordinates } \\
\text { Grid } \\
\text { Resolution }\end{array}$ & $\begin{array}{l}\text { sph. } \\
\text { B } \\
1 / 4^{\circ}\end{array}$ & $\begin{array}{l}\text { sph. } \\
\text { C } \\
0.9^{\circ} \times 0.7^{\circ}\end{array}$ & $\begin{array}{l}\text { sph. } \\
\text { B } \\
1 / 2^{\circ}\end{array}$ & $\begin{array}{l}\text { sph. } \\
\text { B } \\
1 / 6^{\circ}\end{array}$ & $\begin{array}{l}\text { sph. } \\
\text { C } \\
1^{\circ}\end{array}$ & $\begin{array}{l}\text { sph. } \\
\text { B } \\
0.36^{\circ}\end{array}$ \\
\hline $\begin{array}{l}\text { Vertical } \\
\text { Coordinates } \\
\text { Levels } \\
\text { Minimum resolution } \\
\text { Maximum resolution }\end{array}$ & $\begin{array}{l}z \\
30 \\
20 \mathrm{~m} \\
399 \mathrm{~m}\end{array}$ & $\begin{array}{l}\sigma \\
20 \\
1.25 \mathrm{~m} \\
800 \mathrm{~m}\end{array}$ & $\begin{array}{l}z \\
29 \\
10 \mathrm{~m} \\
290 \mathrm{~m}\end{array}$ & $\begin{array}{l}z \\
30 \\
20 \mathrm{~m} \\
200 \mathrm{~m}\end{array}$ & $\begin{array}{l}\rho \\
11 \\
\sim 5 \mathrm{~m} \\
\sim 500 \mathrm{~m}\end{array}$ & $\begin{array}{l}z \\
21 \\
10 \mathrm{~m} \\
790 \mathrm{~m}\end{array}$ \\
\hline External mode & $\mathrm{rl}$ & efs & $\mathrm{rl}$ & ifs & efs & $\mathrm{rl}$ \\
\hline Topography & ETOPO5 & $\begin{array}{l}\text { Global } \\
\text { DTM }\end{array}$ & AOMIP & $\begin{array}{l}\text { ETOPO5 + } \\
\text { other }\end{array}$ & AOMIP & AOMIP \\
\hline $\begin{array}{l}\text { Minimum depth } \\
\text { Maximum depth } \\
\text { Implementation }\end{array}$ & $\begin{array}{l}60 \mathrm{~m} \\
4800 \mathrm{~m} \\
\mathrm{fc}\end{array}$ & $\begin{array}{l}50 \mathrm{~m} \\
6000 \mathrm{~m} \\
-\end{array}$ & $\begin{array}{l}30 \mathrm{~m} \\
4345 \mathrm{~m} \\
\mathrm{fc}\end{array}$ & $\begin{array}{l}45 \mathrm{~m} \\
4300 \mathrm{~m} \\
\mathrm{fc}\end{array}$ & $\begin{array}{l}20 \mathrm{~m} \\
5000 \mathrm{~m} \\
-\end{array}$ & $\begin{array}{l}75 \mathrm{~m} \\
5000 \mathrm{~m} \\
\mathrm{fc}\end{array}$ \\
\hline Mixed layer & none & MY2.5 & none & none & bulk & bulk \\
\hline $\begin{array}{l}\text { Momentum } \\
\text { Horizontal friction } \\
\text { Vertical mixing }\end{array}$ & $\begin{array}{l}\text { bh } \\
\text { const. }\end{array}$ & $\begin{array}{l}\text { Smag. } \\
-\end{array}$ & $\begin{array}{l}\text { Nep. } \\
\text { const. }\end{array}$ & $\begin{array}{l}\text { bh } \\
\text { PP }\end{array}$ & $\begin{array}{l}\mathrm{h} \\
\text { Layer }\end{array}$ & $\begin{array}{l}\mathrm{h} \\
\text { const. }\end{array}$ \\
\hline $\begin{array}{l}\text { Tracer } \\
\text { Advection } \\
\text { Horizontal friction } \\
\text { Vertical mixing } \\
\text { Convective adjustment }\end{array}$ & $\begin{array}{l}\text { FCT } \\
- \\
- \\
\text { fcon }\end{array}$ & $\begin{array}{l}\operatorname{Lin} 94 \\
- \\
\text { MY } \\
-\end{array}$ & $\begin{array}{l}\text { FCT } \\
\text { const. } \\
- \\
\text { fcon }\end{array}$ & $\begin{array}{l}\text { CD } \\
\text { bh } \\
\text { PP } \\
\text { S74 }\end{array}$ & $\begin{array}{l}\text { MPDATA } \\
- \\
\text { McDD } \\
\text { HJ01 }\end{array}$ & $\begin{array}{l}\text { CD } \\
\text { const. } \\
\text { const. } \\
\text { fcon }\end{array}$ \\
\hline
\end{tabular}

Modifications have been applied in narrow passages, depending on the horizontal resolution. Abbreviations are sph.: spherical, rl: rigid lid, efs: explicit free surface, ifs: implicit free surface, fc: full cell, MY: Mellor and Yamada (1982), bh: biharmonic, h: harmonic, Smag.: Smagorinsky formulation, Nep.: neptune (Holloway, 1992), PP: Pacanowski and Philander (1981), FCT: flux corrected transport (Gerdes et al., 1991), L94: Lin et al. (1994), CD: centered differences, MPDATA:Smolarkiewicz (1984), McDD: McDougall-Dewar Scheme for vertical diffusivity (McDougall and Dewar, 1998), fcon: full convection, S74: Semtner (1974), HJ01: Holland and Jenkins (2001).

(2) Heat content of the top $1000 \mathrm{~m}$ in $\mathrm{J} \mathrm{m}^{-2}$, given by:

$$
H=\int_{0}^{1000 \mathrm{~m}} \rho_{w} c_{p}\left(\theta-\theta_{r}\right) \mathrm{d} z,
$$

with potential temperature $\theta$ (relative to $0 \mathrm{db}$ ) referenced to $\theta_{r}=0{ }^{\circ} \mathrm{C}$.

(3) Freshwater content in the upper $1000 \mathrm{~m}$, expressed in $\mathrm{m}$ :

$$
F=\int_{0}^{1000 \mathrm{~m}} \frac{\left(S_{r}-S\right)}{S_{r}} \mathrm{~d} z,
$$

with salinity $S$ referenced to $S_{r}=34.8$. 
Table 2

Sea ice model specifications

\begin{tabular}{lllllll}
\hline & AWI & GSFC & IOS & NPS & NYU & UW \\
\hline Rheology & VP & Vis. & VP & VP & CF & VP \\
Advection & UA & LF & SOM & CD & MPDATA & CD \\
$\begin{array}{l}\text { Ice thickness } \\
\text { Representation }\end{array}$ & 2layer & 2layer & 2layer & 2layer & 2layer & h-dist. \\
Categories & - & - & - & - & - & 12 \\
Snow & Yes & Yes & Yes & No & Yes & Yes \\
\hline
\end{tabular}

Abbreviations are VP: viscous-plastic, Vis.: generalized viscous, CF: cavitating fluid, UA: upstream + antidiffusion (Smolarkiewicz, 1983), LF: leapfrog, SOM: second order moments (Merryfield and Holloway, 2003), CD: centered differences, MPDATA: Smolarkiewicz (1984), h-dist.: ice thickness distribution.

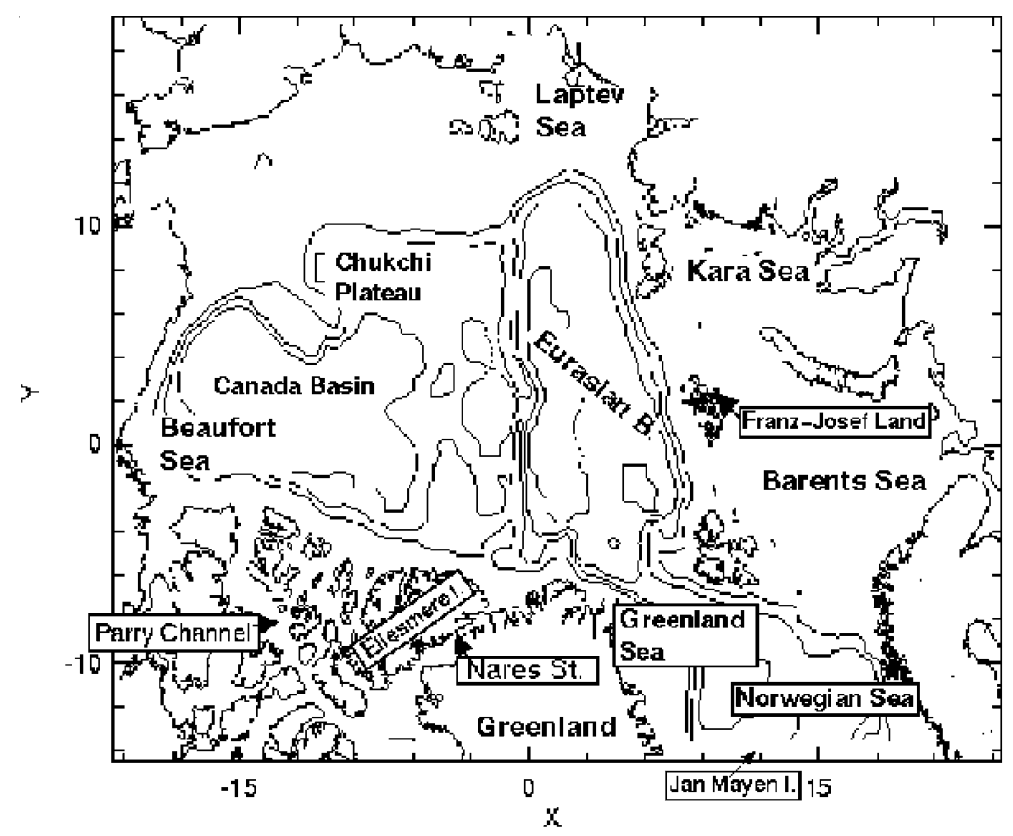

Fig. 1. Common model intercomparison domain.

For comparison heat and freshwater contents derived from the Polar Science Center Hydrographic Climatology (PHC) are included into the discussion. Due to insufficiencies of the monthly PHC fields, only the annual and seasonal (summer, winter) fields are used so far. PHC is a global climatology constructed as a combination of Levitus' 1998 world climatology (WOA) and of the Environmental Working Group (EWG) Arctic only climatology (AOA). These datasets were merged such that PHC retains the high quality world description provided by Levitus while improving the Arctic with the EWG fields. A complete description of the data set can be found in 
Table 3

List of applied forcing for the individual models run with climatological mean forcing

\begin{tabular}{|c|c|c|c|c|}
\hline $\begin{array}{l}\text { Institution } \\
\text { /reference }\end{array}$ & $\begin{array}{l}\text { AWI-c/Karcher } \\
\text { et al. (in press) }\end{array}$ & GSFC-c/Häkkinen (1999) & $\begin{array}{l}\text { IOS-c/Holloway } \\
\text { and Sou (2002) }\end{array}$ & $\begin{array}{l}\text { NYU-c/Holland } \\
(2001)\end{array}$ \\
\hline $\begin{array}{l}\text { Atmospheric } \\
\text { forcing }\end{array}$ & $\begin{array}{l}\text { Daily ECMWF } \\
\text { reanalyses (1979- } \\
\text { 1993) (OMIP1, } \\
\text { Röske (2001)) }\end{array}$ & $\begin{array}{l}\text { Monthly NCEP (1951-1993, } \\
\text { SLP, windspeed) + ECMWF } \\
\text { (1980-1993, } T_{\text {air }}, \text { humidity) } \\
\text { windstress from SLP }\end{array}$ & $\begin{array}{l}\text { Monthly NCEP } \\
\text { (1948-2000), wind- } \\
\text { stress from SLP }\end{array}$ & $\begin{array}{l}\text { Monthly ECMWF } \\
\text { (1979-1993) re- } \\
\text { analyses }\end{array}$ \\
\hline River discharge & none & $4372 \mathrm{~km}^{3}$ year $^{-1}$ & $2445 \mathrm{~km}^{3}$ year $^{-1}$ & None \\
\hline $\begin{array}{l}\text { Boundary condi- } \\
\text { tions }\end{array}$ & $\begin{array}{l}\text { Closed Bering St. } \\
\sim 50^{\circ} \mathrm{N} \text { Atl. inflow } \\
\text { and } T, S \text { from } \\
\text { Levitus } 94\end{array}$ & $\begin{array}{l}\text { Bering St.: } 0.8 \mathrm{~Sv} \text { in } 15^{\circ} \mathrm{S} \\
\text { Atl.:0.8 Sv out restore } T, S \\
\text { to WOA } 82\end{array}$ & $\begin{array}{l}\text { Bering St.: } 0.8 \mathrm{~Sv} \\
\text { in C. Arch.: } 1.0 \text { out } \\
\text { E/W J. Mayen: } 0.2 \\
\text { Sv in inflow } T, S: \\
\text { monthly PHC }\end{array}$ & $\begin{array}{l}\text { Closed N. Pac. at } \\
\sim 60^{\circ} \mathrm{N} \text { closed N. } \\
\text { Atl. at } \sim 60^{\circ} \mathrm{N} \text { re- } \\
\text { store } T, S \text { to PHC } \\
1.0\end{array}$ \\
\hline$T, S$ initial cond. & $\begin{array}{l}\text { EWG/Levitus } 94 \\
\text { merged dataset for } \\
\text { winter }\end{array}$ & Levitus 94 & Dec. PHC & PHC 1.0 \\
\hline Restoring & $\begin{array}{l}S: 180 \mathrm{~d} \text { at } 10 \mathrm{~m} \text { to } \\
\text { annual mean } \\
\text { EWG/Levitus } 94\end{array}$ & None & None & $\begin{array}{l}S: 2 \mathrm{y} \text { over the } \\
\text { mixed layer to } \\
\text { PHC } 1.0\end{array}$ \\
\hline
\end{tabular}

Forcing has been averaged over the given time periods. AWI-c, IOS-c, NYU-c have been integrated for 30 years and GSFC-c for 15 years. The presented results are from the last year of integration. Unless otherwise noted, reanalysis/ analysis provided windstress is used (SLP: sea level pressure).

Table 4

List of applied forcing for the individual models, run in timeseries mode

\begin{tabular}{|c|c|c|c|c|}
\hline $\begin{array}{l}\text { Institution } \\
\text { /reference }\end{array}$ & $\begin{array}{l}\text { AWI-98/Karcher } \\
\text { et al. (in press) }\end{array}$ & $\begin{array}{l}\text { IOS-98/Holloway } \\
\text { and Sou (2002) }\end{array}$ & $\begin{array}{l}\text { NPS-98/Maslowski } \\
\text { et al. (2000) }\end{array}$ & $\begin{array}{l}\text { UW-98/Zhang et al. } \\
(2000)\end{array}$ \\
\hline $\begin{array}{l}\text { Atmospheric } \\
\text { forcing }\end{array}$ & $\begin{array}{l}\text { Daily ECMWFrea- } \\
\text { nalyses (1979-1993), } \\
\text { analyses (1994-1999) }\end{array}$ & $\begin{array}{l}\text { Monthly NCEP } \\
\text { (1948-2000), wind- } \\
\text { stress from SLP }\end{array}$ & $\begin{array}{l}\text { Daily ECMWF rea- } \\
\text { nalyses (1979-1993), } \\
\text { analyses (1994-1998) }\end{array}$ & $\begin{array}{l}\text { Daily IABP/POLES } \\
\text { (1979-1998) windstress } \\
\text { from SLP }\end{array}$ \\
\hline River discharge & None & $2445 \mathrm{~km}^{3}$ year $^{-1}$ & $2012 \mathrm{~km}^{3}$ year $^{-1}$ & $4339 \mathrm{~km}^{3}$ year $^{-1}$ \\
\hline $\begin{array}{l}\text { Boundary } \\
\text { conditions }\end{array}$ & $\begin{array}{l}\text { Closed Bering St. } \\
\sim 50^{\circ} \mathrm{N} \text { Atl. inflow } \\
\text { and } T, S \text { from } \\
\text { Levitus } 94\end{array}$ & $\begin{array}{l}\text { Bering St.: } 0.8 \mathrm{~Sv} \text { in } \\
\text { C. Arch.: } 1.0 \text { out } \mathrm{E} / \mathrm{W} \\
\text { J. Mayen: } 0.2 \mathrm{~Sv} \text { in } \\
\text { inflow } T, S: \text { monthly } \\
\text { PHC }\end{array}$ & $\begin{array}{l}\text { Closed Bering St. } \\
\text { closed N. Atl. at } 50^{\circ} \\
\mathrm{N} \text { restore } T, S \text { to } \\
\text { WOA94 }\end{array}$ & $\begin{array}{l}\text { Bering St.: } 0.8 \mathrm{~Sv} \text { in } \mathrm{C} \text {. } \\
\text { Arch.: } 1.5 \text { out } \mathrm{E} / \mathrm{W} \\
\text { Iceland: } 0.7 \mathrm{~Sv} \text { in restore } \\
T, S \text { to WOA } 82\end{array}$ \\
\hline $\begin{array}{l}T, S \text { initial } \\
\text { cond. }\end{array}$ & $\begin{array}{l}\text { EWG/Levitus94 } \\
\text { merged dataset for } \\
\text { winter }\end{array}$ & Dec. PHC & WOA94 & WOA82 \\
\hline Restoring & $\begin{array}{l}S: 180 \mathrm{~d} \text { at } 10 \mathrm{~m} / \\
\text { EWG-Levitus }\end{array}$ & None & $\begin{array}{l}S: 120 \mathrm{~d} \text { at } 10 \mathrm{~m} T: \\
365 \mathrm{~d} \text { at } 10 \mathrm{~m} \text { monthly } \\
\text { WOA94 }\end{array}$ & $\begin{array}{l}S: 5 \mathrm{y} \text { at } 5 \mathrm{~m} \text { and }>800 \mathrm{~m} \\
T: 5 \mathrm{y} \text { below } 800 \mathrm{~m} \\
\text { annual WOA82 }\end{array}$ \\
\hline
\end{tabular}

Presented results are from year 1998. Unless otherwise noted, reanalysis/analysis provided windstress is used (SLP: sea level pressure).

Steele et al. (2001b). PHC will be used for common temperature and salinity initial conditions and restoring in the upcoming AOMIP phase. 


\section{Results}

\subsection{Streamfunction}

Fig. 2 compares annual mean streamfunction with corresponding seasonal ranges shown in Fig. 3. Results from climatological runs are shown on the left-hand side with results from timeseries runs on the right-hand side. Although the basic streamfunction patterns, with a more or less intense separation between Eurasian and Canada Basin, are quite alike, significant differences arise among the models. The cyclonic circulation in the Eurasian Basin is quite consistent for both climatological and timeseries runs, only the high resolution NPS-98 model pattern is dominated by smaller scale features and does not show an organized circulation. The NYU-c model shows an extremely weak Eurasian Basin circulation.

Less agreement is seen in the Canada Basin, where most models show positive streamfunction values. The GSFC-c results have positive values only in the central Canada Basin and negative values at the margins. Neglecting smaller scale structures, the NPS-98 model tends towards a similar picture. The NYU-c results with a maximum of $8.4 \mathrm{~Sv}$, show the highest value in the annual mean. However, the NYU-c run exhibits profound month to month variability in the Canada Basin (Fig. 3), with a maximum of about $20 \mathrm{~Sv}$ in December, and cyclonic mass transport with up to -7 Sv in August/ September. Thereby in winter only one large circulation cell is present, in summer two circulation cells develop with cyclonic mass transport in the Canada Basin and anticyclonic transport over the Chukchi Plateau area. This intense cycle corresponds to significant seasonal changes in the upper layer velocities, which are caused by strongly anticyclonic winds in winter, compared to summer winds, which include a cyclonic component in the Western Arctic. The transport at depth does not change greatly. AWI-c uses ECMWF based daily wind forcing, covering the same timeperiod, however shows a much weaker seasonal range. The NYU model also shows an extremely large vertically integrated kinetic energy in the Arctic Basin (Uotila, pers. comm.), supporting the suggestion, that the momentum flux between atmosphere, ice and ocean is more intense in the NYU-model. The IOS-c as well as the IOS-98 results show cyclonic mass transport in the Canada Basin the whole year round. The seasonal range is extremely low (below $0.5 \mathrm{~Sv}$ ). As for all other models, the IOS model surface circulation is anticyclonic. However, related to the applied neptune parameterization it changes at depths lower than $200 \mathrm{~m}$ into an enhanced cyclonic circulation, which dominates the streamfunction. Since this also holds for the timeseries results, the differences between IOS-c and IOS-98 are rather low. The closest similarity to the IOS circulation pattern can be found in the GSFC-c run, which may be related to a tendency of $\sigma$-models to produce more topographically controlled currents (e.g, Barnard et al., 1997).

The seasonal range in the GSFC-c results reaches a maximum of $2 \mathrm{~Sv}$ total range in the Eurasian Basin and larger values in the Greenland and Norwegian Seas. Over a single year NPS98 and AWI-98 show high ranges in the Norwegian Sea, lower ranges in the Eurasian Basin and almost zero range in the Canada Basin. AWI-c and UW-98 show a low seasonal range with values below $2 \mathrm{~Sv}$ in the whole domain.

\subsection{Heat content}

Fig. 4 shows the annual mean heat contents integrated over the top $1000 \mathrm{~m}$ for the individual models and from climatology data (PHC). The corresponding seasonal ranges are shown in Fig. 5. 

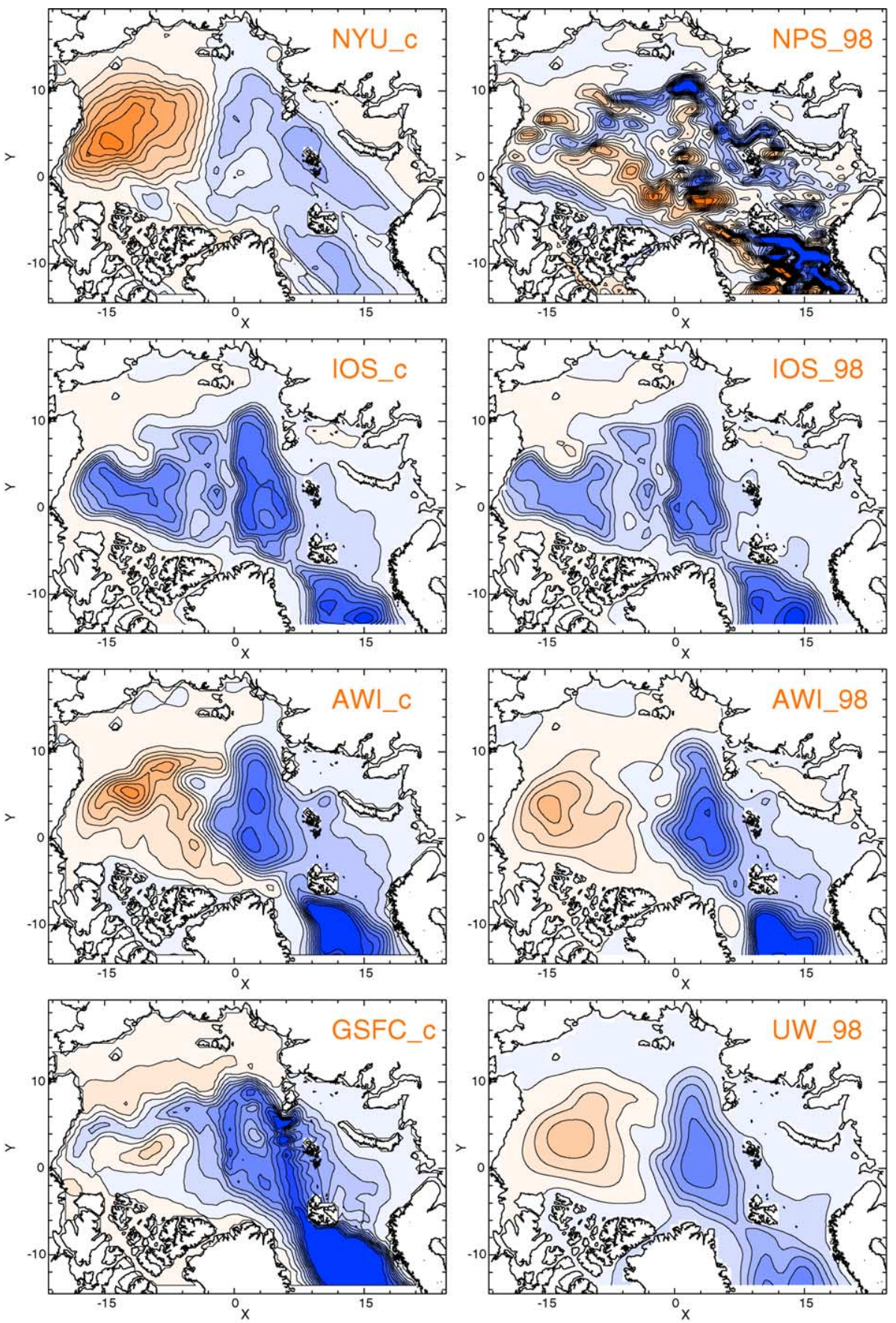

$-10$

$$
-6
$$

$-2$

2

6

10

Fig. 2. Model representations of annual mean streamfunction in Sv. 

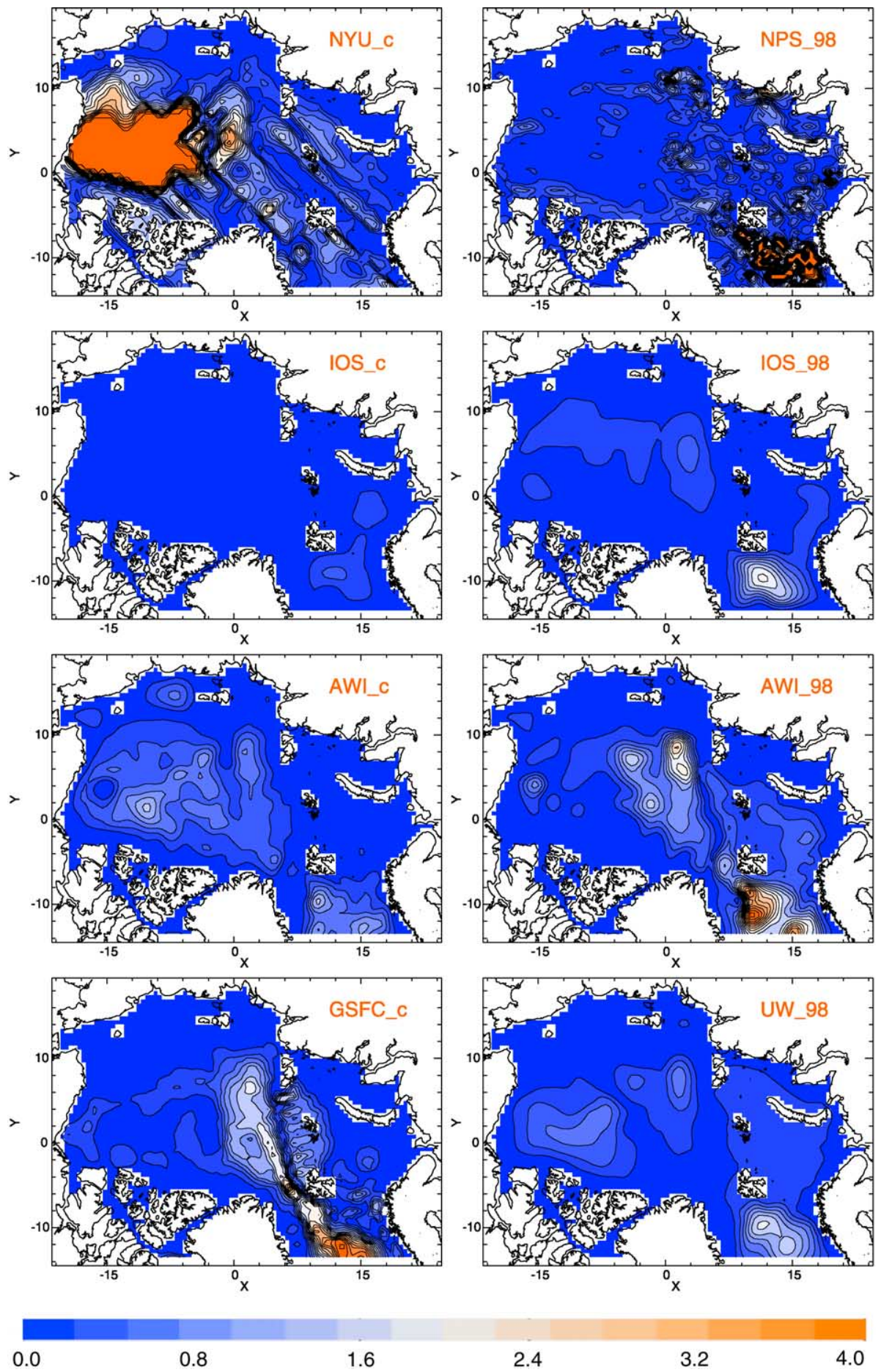

Fig. 3. Model representations of the annual streamfunction range in Sv. 
All models show the offshoot of warm and salty Atlantic water penetrating into the Arctic Ocean via Fram Strait and Barents Sea, but obvious differences of the model responses are visible in the Eurasian and Canada Basin. The heat content varies from -3.8 to $0.8 \mathrm{GJ} \mathrm{m}^{-2}$ in the eastern Nansen Basin and from -3.5 to $1.8 \mathrm{GJ} \mathrm{m}^{-2}$ in the Canada Basin, showing both higher and lower values compared to PHC with 0.4 and $-0.8 \mathrm{GJ} \mathrm{m}^{-2}$ in the Nansen and Canada Basin.

Differences between the simulated heat contents can be related to differences in the representation of the Atlantic water pathways through Fram Strait and Barents Sea. The lowest values are correlated with a sharp front already in Fram Stait, suggesting an underestimation of the Atlantic water inflow via Fram Strait (e.g. NYU). The weak streamfunction in the Eurasian Basin supports this suggestion. Low heat content can also be caused by too cold water entering the Eurasian Basin via St. Anna Trough. The Barents Sea branch of the Atlantic Water inflow thus becomes very cold and fills the Eurasian Basin at mid depth with a very cold water mass (e.g. AWI-c run in this study). Another cause for low heat content is related to an overestimated heat loss from ocean to atmosphere, most intensely in the Nansen Basin, cooling the inflowing Atlantic Water too rapidly (e.g. IOS-98). The IOS model also shows a strong response to variations of the sensible and latent heat exchange coefficients $c_{e}$ and $c_{q}$. For IOS-98 a change from $c_{e}=0.0012$ and $c_{q}=0.0015$ (AOMIP standard) to values of $c_{e}=c_{q}=0.00175$ as used in previous studies leads to a reduction of 1.3-1.8 $\mathrm{GJ} \mathrm{m}^{-2}$ in the Arctic Basin. For IOS-c the reduction is less $\left(\sim 0.4 \mathrm{GJ} \mathrm{m}^{-2}\right)$.

High heat content, in contrast, can be caused by an underrepresentation of cold Barents Sea Branch water (e.g. GSFC). AWI-98, shows a warm water anomaly in the Amundsen and Makarov Basins, which is attributed to the early 1990s warming event (Karcher et al., in press); however by 1998 this warm water anomaly did not yet reach the central Canada Basin. Hence, for the high heat content in the Canada Basin, which can be found in the NPS-98 run other reasons need to be responsible: First an underestimation of the eastward propagation along the Laptev Sea shelf, which affects the transport of cold Barents Sea Branch water. Second, problems with heat transported from the restored surface layer towards deeper layers seem to occur for integrations over long time scales in the NPS model (NPS-98 is after more than 240 years total integration).

The seasonal range of the vertically integrated heat content (Fig. 5) is largest in the Greenland, Norwegian and Barents Seas, areas with seasonal or no ice cover to block the heat exchange between ocean and atmosphere and, correspondingly, larger fluxes. For the same reason, increased values can also be found in the marginal ice zones around the entire Arctic Ocean. The highest range can be found in the GSFC-run in the shallow regions of the Barents and Kara Seas. This is related to a much larger heat advection into this area for the GSFC model, which has been found in a separate study. The ranges are about $3 \mathrm{GJ} \mathrm{m}^{-2}$ with maxima around $6 \mathrm{GJ} \mathrm{m}^{-2}$. In most models the seasonal range in the central Arctic is close to zero, with higher values only for the NYU model, where the heat content is affected by the change in the circulation pattern from summer to winter. Higher variability in the Beaufort Sea is related to extremely light ice conditions in the Beaufort Sea in 1998 (Melling, pers. comm.).

PHC shows a range pattern similar to most of the runs (Fig. 5), however with increased seasonal variability also in the Nansen Basin. Averaged over the Barents Sea, Siberian Shelves and Beaufort Sea/Canada Basin, most simulated seasonal ranges are quite close to the PHC range, which is indicated by the summer and winter averages in Fig. 6. As noted already earlier, the largest seasonal range can be found in the GSFC-c run, most obviously over the Siberian Shelves. 

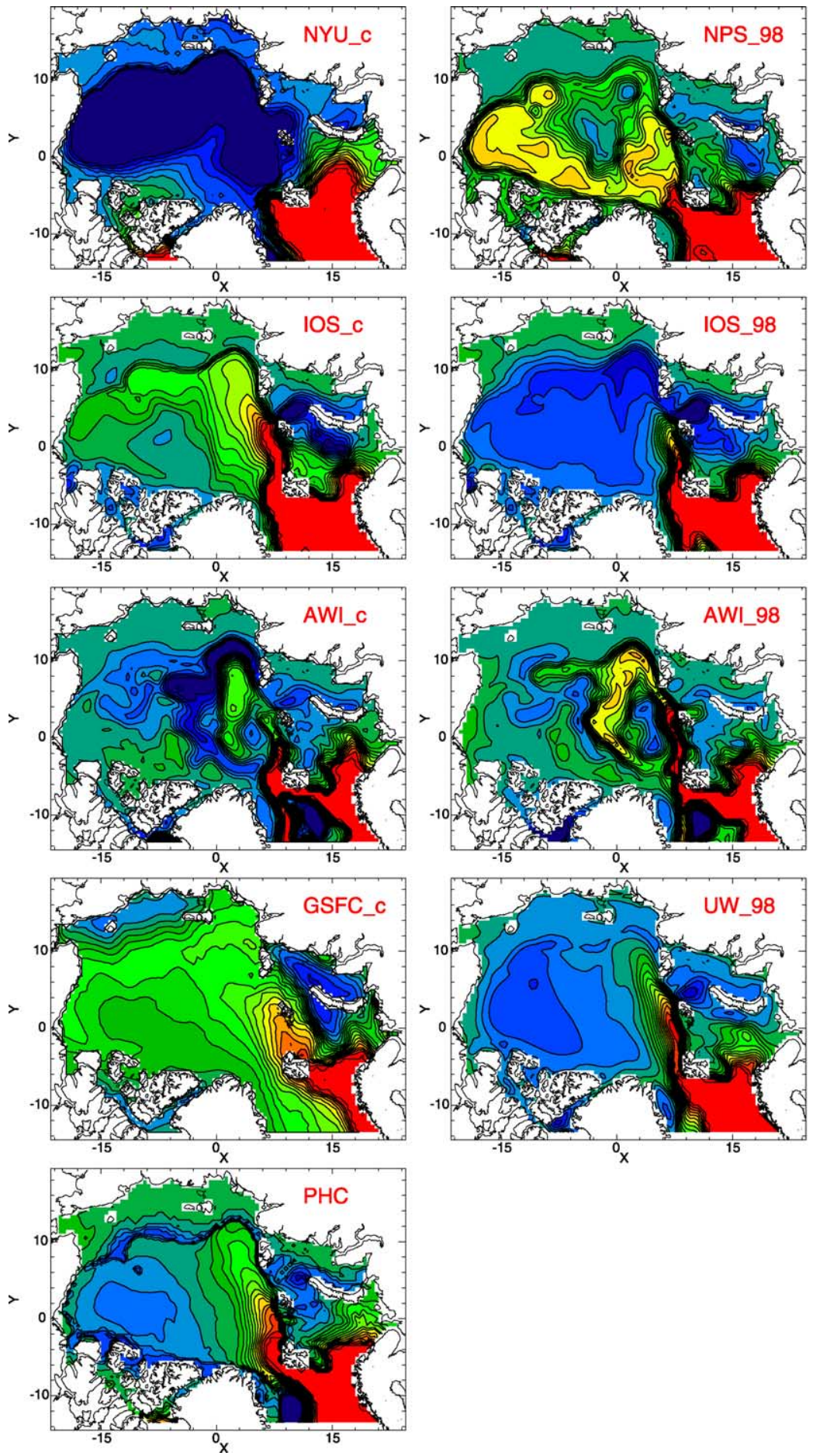

Fig. 4. Model representations of annual mean heat content in the top $1000 \mathrm{~m}$, given in $\mathrm{GJ} \mathrm{m}^{-2}$. 

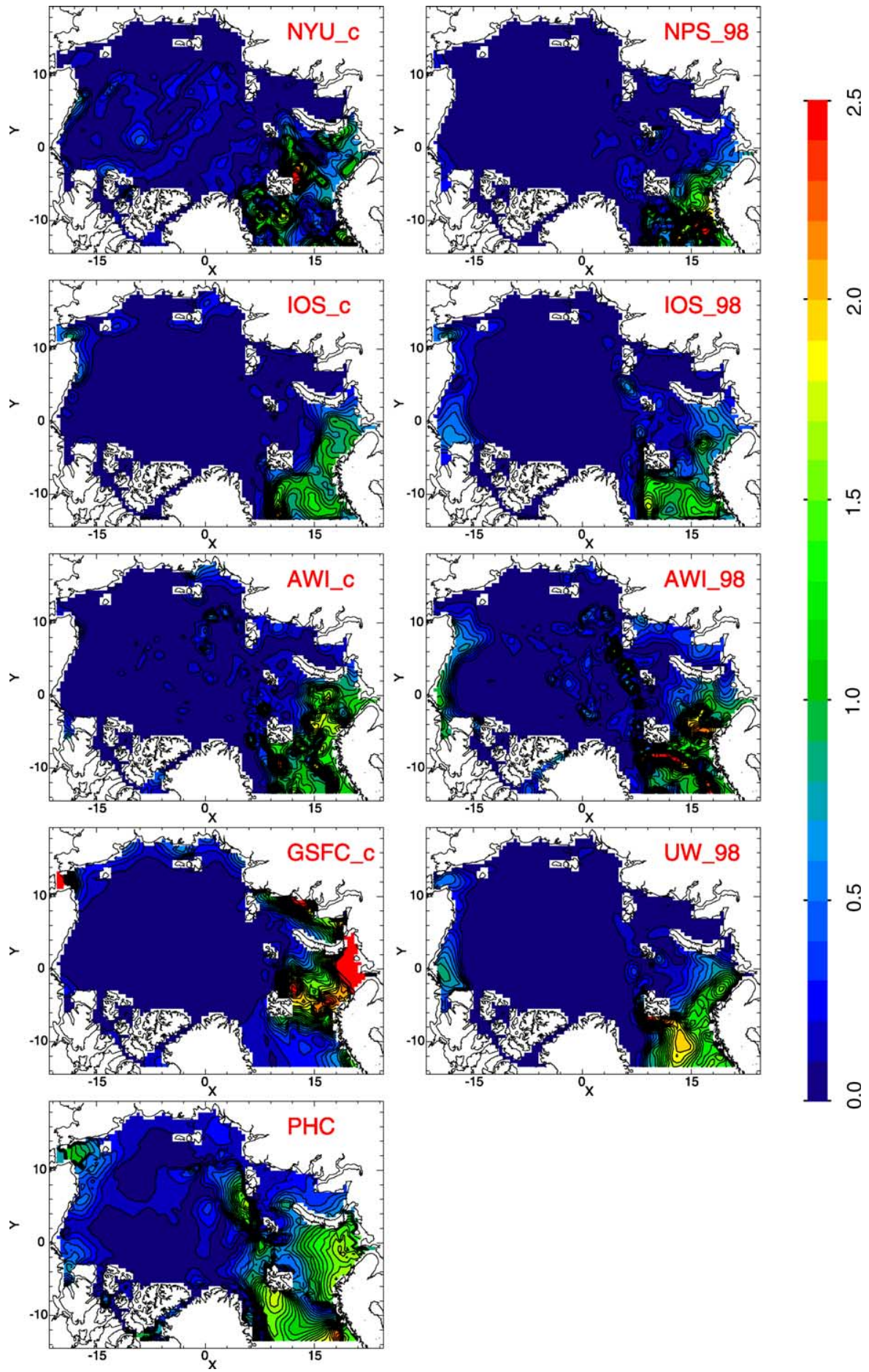

Fig. 5. Seasonal range of heat content in the top $1000 \mathrm{~m}$, given in $\mathrm{GJ} \mathrm{m}^{-2}$. Seasonal range is defined by the difference between March/April/May and July/August/September. 

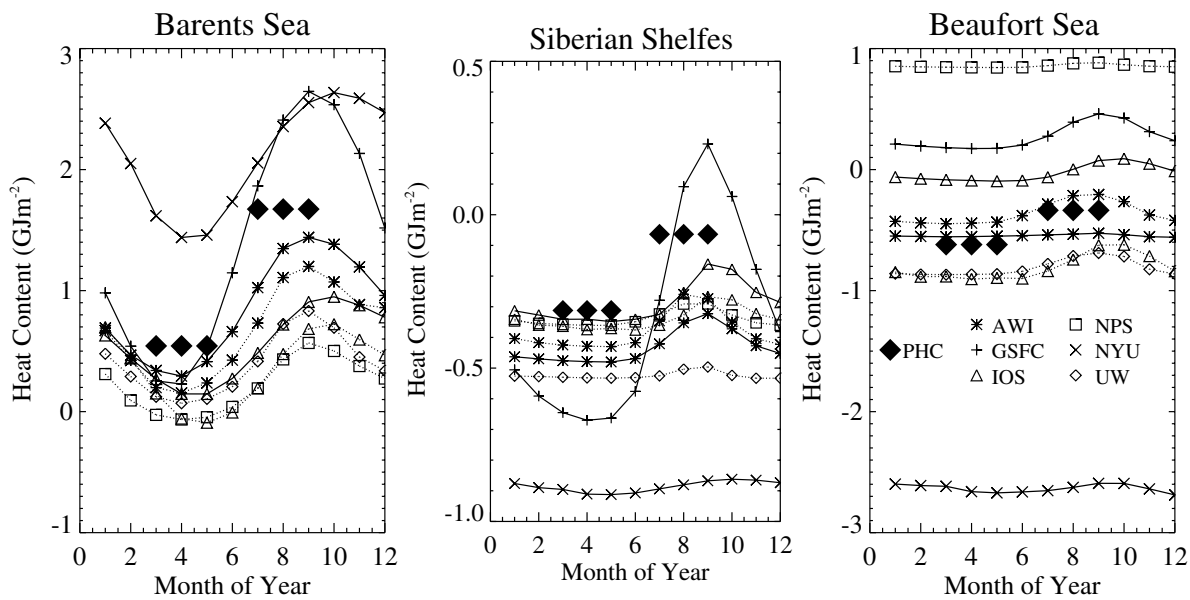

Fig. 6. Seasonal cycle of heat content in the top $1000 \mathrm{~m}_{\text {in GJ m}}^{-2}$, averaged over the regions of Barents Sea $(<80 \mathrm{~N}$, 20E-55E) Siberian Shelves ( $<75 \mathrm{~N}, 55 \mathrm{E}-180 \mathrm{E})$ and Beaufort Sea/Canada Basin $(<80 \mathrm{~N}, 130 \mathrm{~W}-160 \mathrm{~W})$. Dotted lines denote 1998 results, solid lines correspond to climatological mean forcing. Filled diamonds denote summer and winter averaged PHC.

Fig. 6 also points out the large deviations among the models and between models and climatology. Compared to the PHC summer and winter averages, the heat content in the Barents Sea as well as on the Siberian Shelves is lower for most models the whole year round. The deviation is largest for the NYU-c run, which shows higher heat content in the Barents Sea and extremely low heat content in the Beaufort Sea and over the Siberian Shelves. Apart from the large bias for the NPS-98 heat content in the Beaufort Sea/Canada Basin, Fig. 6 shows fairly good agreement with PHC for all 1998 results.

As an example for wind forcing and corresponding freezing conditions, Fig. 7 shows geostrophic wind as well as the number of freezing degree-days per year, i.e. the sum of the mean daily negative air temperatures, for the NCEP forcing, as used for the IOS-c and IOS-98 runs.

Fig. 7c and d shows a shorter freezing period for year 1998 than for the climatological mean in the whole Arctic Basin and most intensly in the Beaufort Sea. Moreover Fig. 7a and b shows stronger geostrophic winds over the Beaufort Sea in 1998, caused by a shift in the location of the high pressure center over the Canada Basin, which affects the ice cover as well as the seasonal ranges of heat and freshwater contents.

\subsection{Freshwater content}

Freshwater content also differs among the models (Fig. 8). In the Canada Basin maximum values vary between about 6 and $24 \mathrm{~m}$, compared to about $17 \mathrm{~m}$ in PHC. Most models show an explicit maximum.

Both the $1000 \mathrm{~m}$ integrated heat and freshwater contents are largely determined by the warm and salty Atlantic water. Within the Eurasian Basin models show a close correspondence between high heat and low freshwater content. In the Canada Basin, however, the freshwater content is influenced by other processes as well, including sensitivity to applied wind forcing. A sensitivity study, carried out with the IOS model, shows that river discharge affects the freshwater maximum 

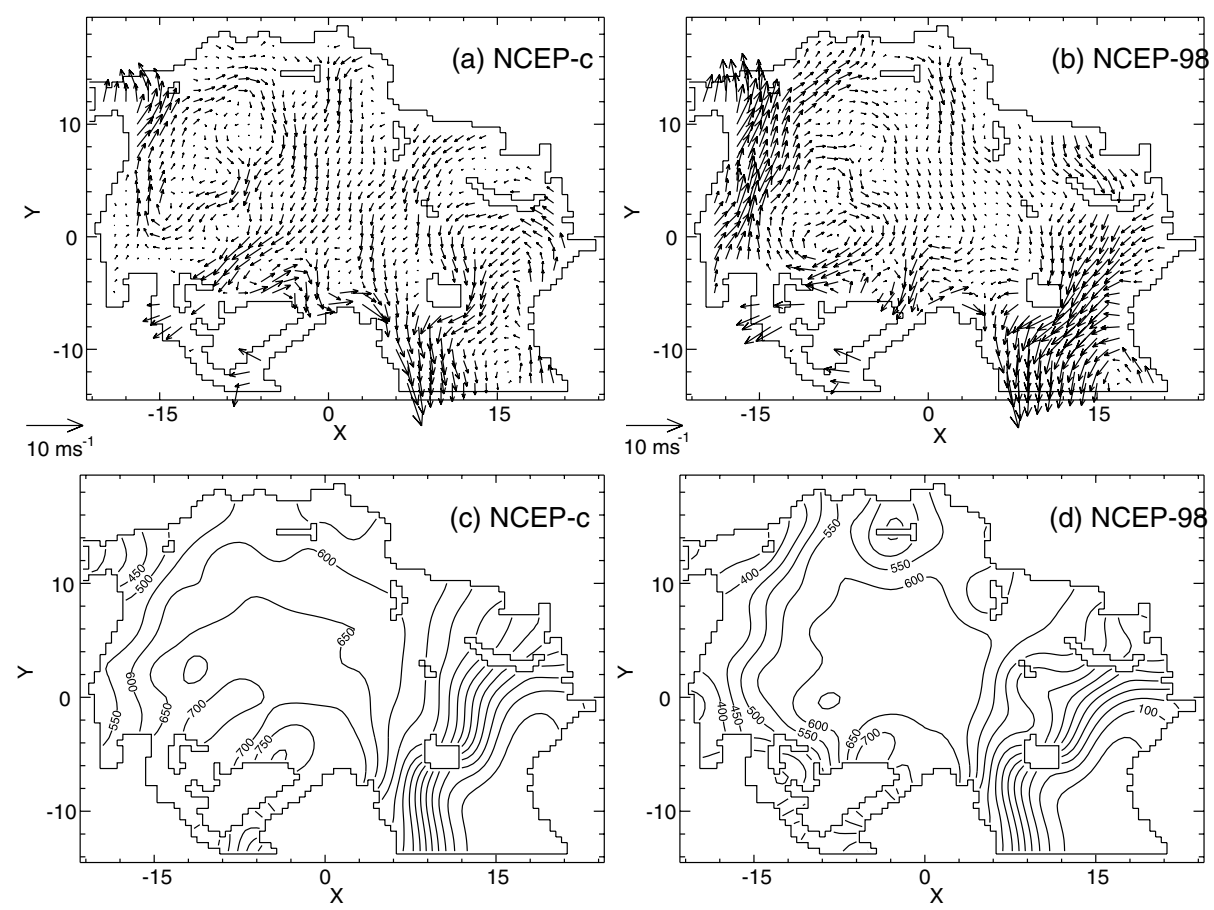

Fig. 7. Geostrophic winds for (a) climatological mean NCEP forcing (IOS-c) and (b) 1998 NCEP forcing (IOS-98). Corresponding number of freezing degree-days per year (multiplied by -0.1) for (c) the climatological mean and (d) 1998. Extension -c denotes the climatological mean, averaged from 1948 to 2000, and extension -98 stands for the annual mean of year 1998.

in the Beaufort Sea less effectively than changes in the wind forcing. Including ungauged river runoff along the coast, which changes the yearly discharge from 2445 to $3249 \mathrm{~km}^{3}$, increases the freshwater content in the Beaufort Sea by $0.9-1 \mathrm{~m}$. Variations in wind forcing fields can account for up to $4 \mathrm{~m}$ within the same model (Steiner et al., 2003). The tongue of salty Atlantic Water entering the Arctic Ocean via Fram Strait, indicated in blue in Fig. 8 is represented quite differently between the models. For UW-98 as well as for both AWI runs the salty tongue penetrates as far as into the Amundsen Basin, for GSFC-c and NPS-98 as well as for PHC saline Atlantic Water can be found up to Franz-Josef-Land. For both IOS representations freshwater content is already increased slightly north of Fram Strait. The NYU simulation, in contrast, shows extremely low freshwater content in the whole Eurasian Basin as well as north of Greenland and Ellesmere Island.

For models with explicit river runoff the seasonal range in freshwater content, shown in Fig. 9, is generally highest along the coast, where the seasonal cycle of river inflow adds to ice growth and melt effects in relatively shallow water. An exception is the NYU-c run, where the freshwater content is affected by the intense streamfunction variation and AWI-98, which shows higher values in a large part of the Arctic Ocean. For AWI-98, which does not include explicit river discharge, the seasonal range is largely determined by ice melt and freeze. Fig. 9 shows a larger seasonal range in the Beaufort Sea for the 1998 results, corresponding to the light ice conditions in 1998. PHC suggests a rather large seasonal cycle in the Beaufort Sea as well as in large parts of the 

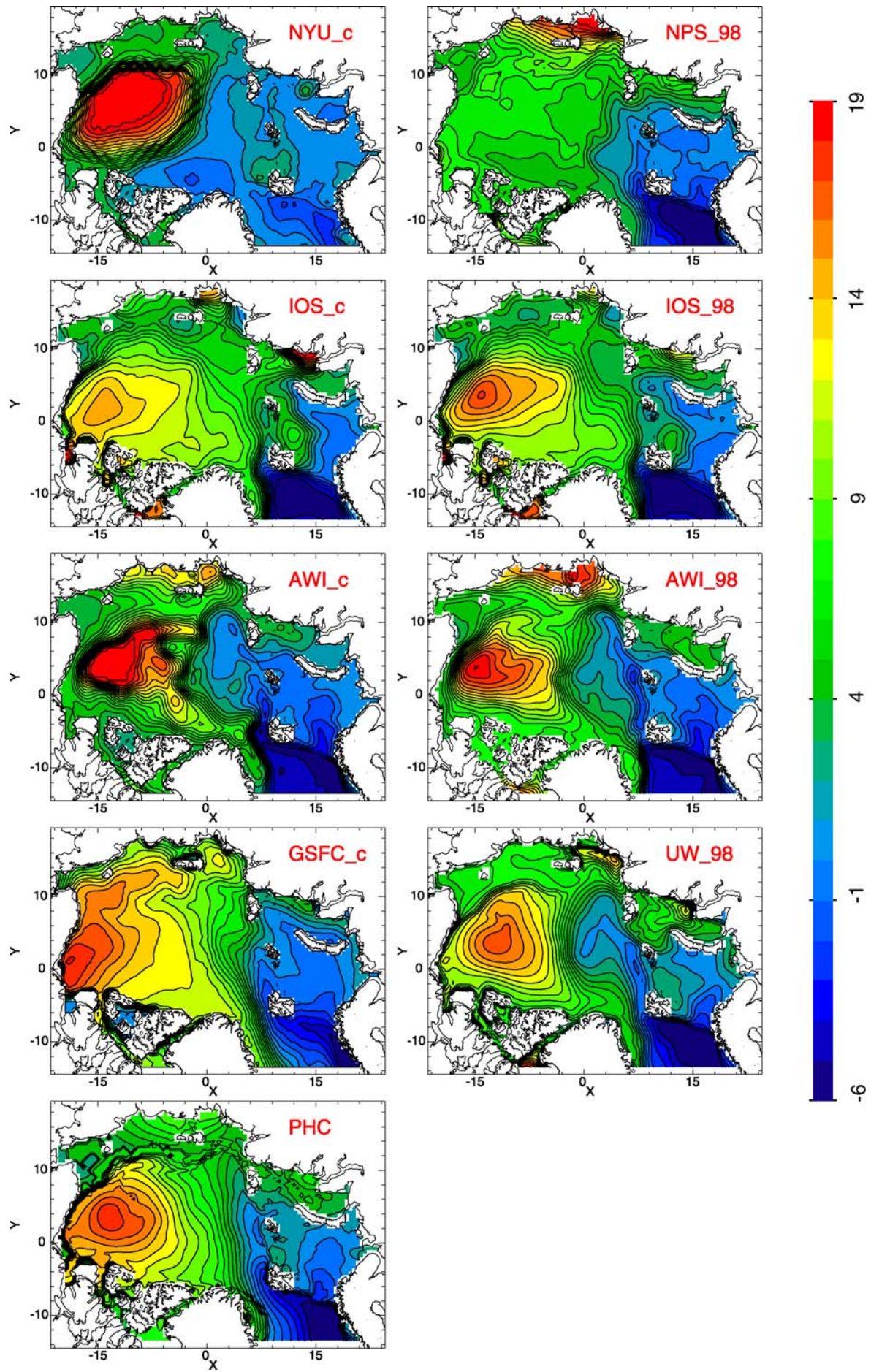

Fig. 8. Model representations of annual mean freshwater content in the top $1000 \mathrm{~m}$, given in $\mathrm{m}$. 

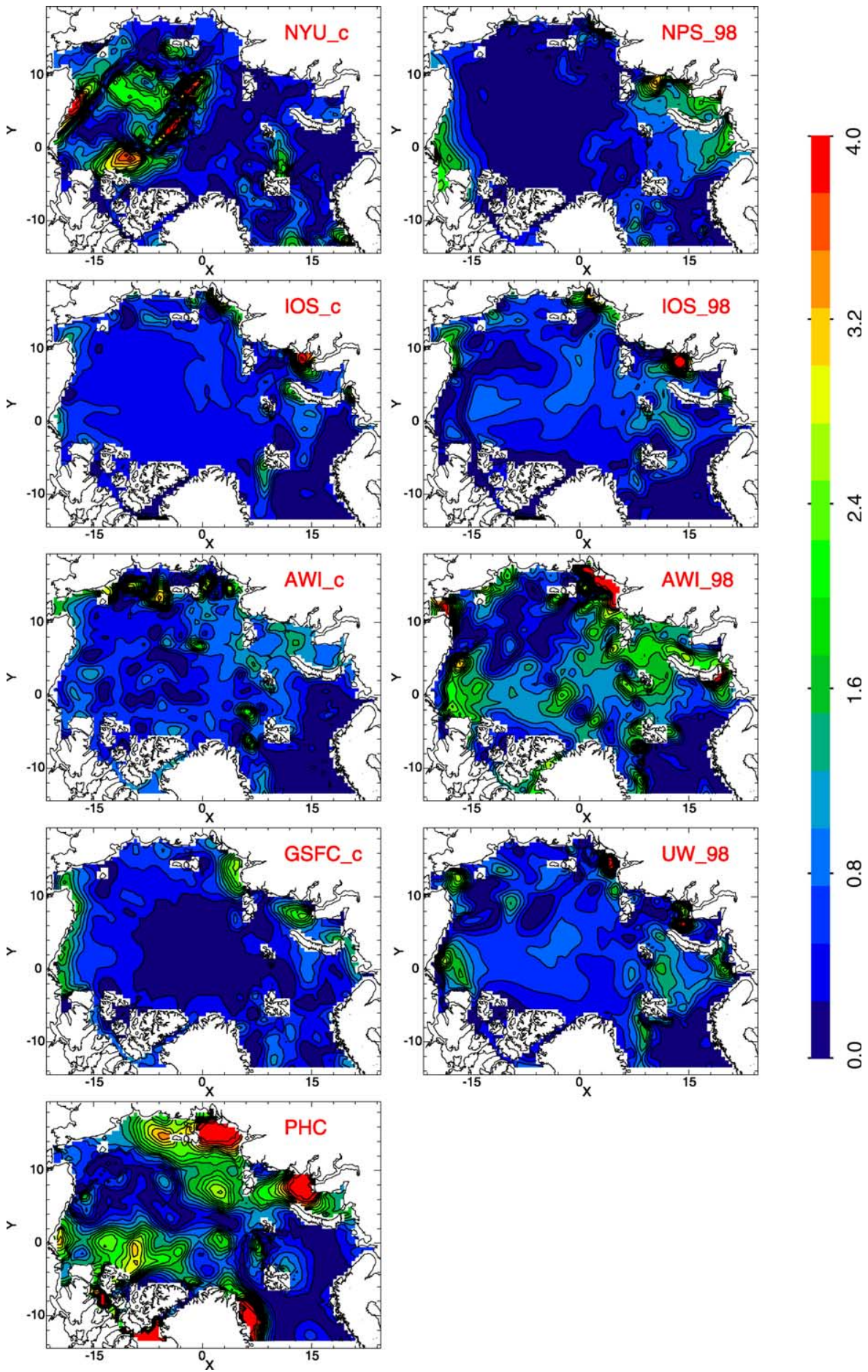

Fig. 9. Seasonal ranges of freshwater content in the top $1000 \mathrm{~m}$, given in $\mathrm{m}$. Seasonal range is defined as in Fig. 5. 

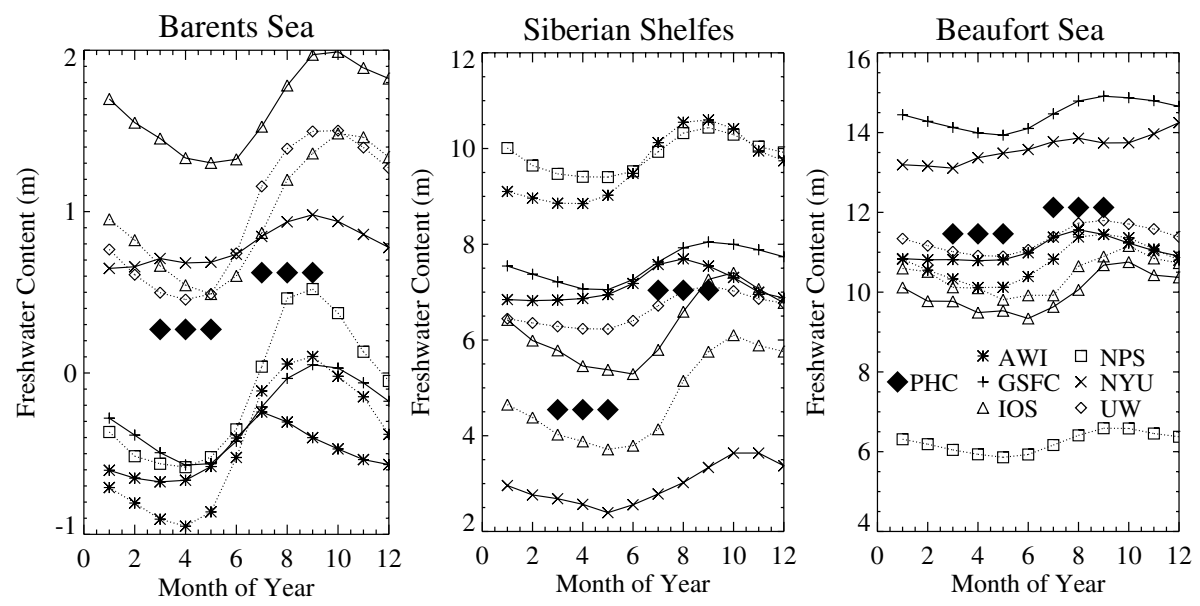

Fig. 10. As Fig. 6 for the freshwater content in the top $1000 \mathrm{~m}$. Unit is meter.

Canada Basin. However it might be that the reason for the large PHC seasonal range is partially due to a hidden interannual variability in the PHC seasonal averages.

Fig. 10 shows the differences among models and climatology averaged over Barents Sea, Siberian Shelves and Beaufort Sea/Canada Basin (note different scales for the regions). Although there is no obvious over- or underestimation from all models the biases are still striking. Values deviate by about $2 \mathrm{~m}$ on the Siberian Shelves and in Barents Sea and by $7 \mathrm{~m}$ in the Canada Basin. Some models group very closely around the climatology, with a deviation of less than a meter in the Canada Basin.

\section{Discussion}

So far, the models have only been run with non-coordinated forcing. However, even at this stage, can we begin to identify causes of some of the differences?

In the current stage of AOMIP, where atmospheric forcing is not standard, differences of forcing appear to be the main contributor in creating differences among model results. OMIPforcing (AWI-c in this study) leads to very cold intermediate water produced in the Barents Sea which enters the Arctic Ocean via St. Anna Trough. Using the same OMIP-forcing the IOS-model produces a similar pattern as AWI-c with cold water production in the Barents Sea and even lower heat contents in the eastern Nansen and Canada Basins (Steiner et al., 2003, their Fig. 9). Continued forcing with the same dataset leads to even further cooling of the Arctic Ocean. The timeseries run AWI-98 does not show this intense cooling. In contrast, it very well represents the warm water inflow, that has been observed in the early nineties (e.g., Carmack et al., 1995; Swift et al., 1997; McLaughlin et al., in press). An extremely cold state is also reached in the NYU-c run, where, as for AWI-c, the wind forcing is based on ECMWF analyses (1979-1993). Interesting is the large difference between the IOS-c run, which tends to a rather warm state, and IOS-98, where the same forcing has been applied in a timeseries mode and a much colder state is reached 
after 50 years of integration. An analysis of the IOS-model timeseries integration shows representations of observed cooling and freshening events in the Nansen Basin, which are attributed to changes in the outflow from Barents Sea into the Arctic Ocean (e.g. Woodgate et al., 2001). However, it does not seem to appropriately represent warm events, attributed to changes of the inflow at Fram Strait. This might be related to the location of the open boundary in the IOS model, which does not cover the source regions Faroe-Scotland Ridge and the southern Nordic Seas. Both regions have been found to be important for the Atlantic Water characteristics further north (e.g. Karcher et al., in press). Since the climatological averaged forcing does not provoke an obvious cooling event, IOS-c is much warmer than the IOS-98 run.

Evaluating wind forcing, it is not only important which data source is used and over which timeperiods climatological forcing has been averaged, but also how windstress is determined (e.g., from sea level pressure or as provided by the source institution). Steiner et al. (2003) find quite strong responses of heat and freshwater contents to different windstress representations, applied over a 40 year time period, which account for differences of up to $1 \mathrm{GJ} \mathrm{m}^{-2}$ in heat content and freshwater changes of a few meters. In those cases the effect of wind on the Fram Strait inflow and the propagation within Nansen Basin as well as cooling and freshening events, related to the Barents Sea outflow are the decisive factors. The effect of river discharge, precipitation and ice melt on the vertical integrated heat and freshwater content in the central Arctic is less intense.

Differences attributed to model parameterizations are limited, so far. Streamfunction is strongly affected by parameterizations for eddy-topography interaction (neptune effect), leading to negative streamfunction values in the Canada Basin for the IOS model. Without neptune the IOS model leads to a pattern more like the NYU annual mean, with weak Eurasian Basin circulation and anticyclonic circulation with a maximum of about $2 \mathrm{~Sv}$ in the Canada Basin. The seasonal range remains low. Streamfunction is also somewhat affected by the choice of the vertical coordinate, where $\sigma$-model currents tend to be more topographically controlled.

Variations of parameters as, e.g., sensible and latent heat exchange coefficients have a quite large effect, especially on the simulated heat content. Additional factors responsible for deviations in vertically integrated heat and freshwater contents, which have not yet been evaluated in detail, are differences in the vertical resolution as well as coarse horizontal resolution along with bathymetry smoothing. In the DYNAMO study local processes like sensitivity to small scale details of the bathymetry turned out to have large-scale implications, e.g. by affecting pathways of boundary currents. In the Arctic the Atlantic Water pathway through the relatively shallow Barents Sea is one example that might be affected. These and other ideas related to the influence of resolution as well as the influence of mixing will be addressed more carefully in the upcoming project stage.

\section{Conclusions}

Within the first stage of AOMIP output of six coupled sea ice--ocean models covering the Arctic Ocean are compared. Vertically integrated measures (streamfunction, heat and freshwater content) have been evaluated. Streamfunction differs by more than $10 \mathrm{~Sv}$ in the mean and shows an even higher seasonal range for one model. A difference of up to $5 \mathrm{GJ} \mathrm{m}^{-2}$ can be found for the heat content in the top $1000 \mathrm{~m}$ of the Canada Basin, as well as a difference of several meter excess 
freshwater in the upper $1000 \mathrm{~m}$ of the Central Canada Basin. The bandwidth of results reflects uncertainties of Arctic Ocean model design, parameterization and forcing. Although that hints to a large variety of possible sources, all choices are reasonable within the individual interests and limitations. The spread of results thus has to be taken seriously as our current state of modeling of this region that not only depends on the interior properties of the models but also on exterior quantities like the forcing fields and the initial conditions. Explanations for several observed differences have been addressed and evaluated as far as possible in the current state of the project. These evaluations will serve as a base for further discussions in the upcoming AOMIP phase, where all participants have agreed upon common forcing datasets, initial conditions, restoring and bathymetry. The current intercomparison will then be repeated with focus on effects arising from model architectures and parameterizations.

\section{Acknowledgements}

The work was supported by IARC grants and additionally from DFO-Canada grants (N.S., G.H.), NSF/OPP grants (W.M.; D.H., OPP-0084286; M.S, OPP-N00014-99-1-0054), Nasa headquarters (S.H.), NASA grants (J.Z.), the German project DEKLIM (R.G.,F.K, grant 01LD0047) and the German-Russian project SIRRO (M.K., grant 03 G 0547B).

\section{References}

Barnard, S., Barnier, B., Beckmann, A., Böning, C., Coulibaly, M., DeCuevas, D., Dengg, J., Dieterich, C., Ernst, U., Hermann, P., Jia, Y., Killworth, P.D., Kröger, J., Lee, M.-M., LeProvost, C., Molines, J.-M., New, A.L., Oschlies, A., Reynaud, T., West, L.J., Willebrand, J., 1997. Dynamo: dynamics of North Atlantic models. Dynamo Scientific Report 3, Laboratoire des Ecoulements Géophysiques et Industriels, Grenoble, Southampton Oceanography Centre, Southampton, Institut für Meereskunde, Kiel.

Carmack, E.C., MacDonald, R.W., Perkin, R.G., McLaughlin, F.A., Pearson, R.J., 1995. Evidence for warming of Atlantic water in the Southern Canadian Basin of the Arctic Ocean: results from the Larson-93 expedition. Geophysical Research Letters 22, 1061-1064.

Gerdes, R., Coeberle, C., Willebrandt, J., 1991. The influence of numerical advection schemes on the results of ocean general circulation models. Climate Dynamics 5, 211-226.

Häkkinen, S., 1999. A simulation of thermohaline effects of a great salinity anomaly. Journal of Climate 12, 1781-1795.

Holland, D.M., 2000. Merged IBCAO/ETOPO5 global topographic data product. National Geophysical Data Center (NGDC), Boulder, Colorado. Available from <http://www.ngdc.noaa.gov/mgg/bathymetry/arctic/ibcaorelatedsites.html>.

Holland, D.M., 2001. An impact of sub-grid-scale ice-ocean dynamics on sea ice cover. Journal of Climate 14, 15851601.

Holland, D.M., Jenkins, A., 2001. Modeling thermodynamic ice ocean interactions at the base of an ice shelf. Monthly Weather Review 129, 1905-1927.

Holloway, G., 1992. Representing topographic stress for large-scale ocean models. Journal of Physical Oceanography 22, 1033-1046.

Holloway, G., Sou, T., 2002. Has Arctic sea ice rapidly thinned? Journal of Climate 15, 1691-1701.

Karcher, M.J., Gerdes, R., Kauker, F., Köberle, C., in press. Arctic warming - evolution of the 1990s warm event in the Nordic Seas and the Arctic Ocean. Journal of Geophysical Research. 
Lin, S.-J., Chao, W.C., Sud, Y.C., Walker, G.K., 1994. A class of van leer-type transport schemes and its application to the moisture transport in a general circulation model. Monthly Weather Review 122, 1575-1593.

Manabe, S., Stouffer, R., Spelman, M., Bryan, K., 1991. Transient responses of a coupled ocean-atmosphere model to gradual changes of atmospheric $\mathrm{CO}_{2} 2$, part I: annual mean response. Journal of Climate 4 (8), 785-818.

Maslowski, W., Newton, B., Schlosser, P., Semtner, A., Martinson, D., 2000. Modeling recent climate variability in the Arctic Ocean. Geophysical Research Letters 27, 3743-3746.

McDougall, T.J., Dewar, W.K., 1998. Vertical mixing and cabeling in layered models. Journal of Physical Oceanography 28, 1458-1480.

McLaughlin, F., Carmack, E., Macdonald, R., Weaver, A.J., Smith, J., in press. The Canada Basin 1989-1995: upstream events and far-field effects of the Barents Sea. Journal of Geophysical Research.

Mellor, G.L., Yamada, T., 1982. Development of a turbulence closure model for geophysical fluid problems. Review in Geophysics 20, 851-875.

Merryfield, W.J., Holloway, G., 2003. Application of an accurate advection algorithm to sea-ice modelling. Ocean Modelling 5 (1), 1-15.

Morison, J.H., Steele, M., Andersen, R., 1998. Hydrography of the upper Arctic Ocean measured from the nuclear submarine USS Pargo. Deep Sea Research I (45), 15-38.

Nazarenko, L., Holloway, G., Tausnev, N., 1998. Dynamics of transport of Atlantic signature in the Arctic Ocean. Journal of Geophysical Research 103 (C13), 31003-31015.

Pacanowski, R.C., Philander, S., 1981. Parameterization of vertical mixing in numerical models of tropical oceans. Journal of Physical Oceanography 11, 1443-1451.

Proshutinsky, A., Steele, M., Zhang, J., Holloway, G., Steiner, N., Häkkinen, S., Holland, D., Gerdes, R., Coeberle, C., Karcher, M., Johnson, M., Maslowski, W., Walczowski, W., Hibler, W., Wang, J., 2001. Multinational effort studies differences among Arctic Ocean models. EOS 82 (51), 637, 643-644.

Rind, D., Healy, R., Parkinson, C., Martinson, D., 1995. The role of sea ice in $2 \times \mathrm{CO}_{2}$ climate model sensitivity. Part I: the total influence of sea ice thickness and extent. Journal of Climate 8, 449-463.

Röske, F., 2001. An atlas of surface fluxes based on the ECMWF re-analysis-A climatological dataset to force global ocean general circulation models. Tech. Rep., Max-Planck-Institut für Meteorologie.

Rothrock, D., Yu, Y., Maykut, G., 1999. Thinning of the Arctic sea ice cover. Geophysical Research Letters 26, 3469-3472.

Semtner, A.J., 1974. An ocean general circulation model with bottom topography. Tech. Rep. 9, University of California, Los Angeles, 99pp.

Smolarkiewicz, P.K., 1983. A simple positive definite advection scheme with small implicit diffusion. Monthly Weather Review 111, 479-486.

Smolarkiewicz, P.K., 1984. A fully multidimensional positive definite advection transport algorithm with small implicit diffusion. Journal of Computational Physics 54, 325-362.

Steele, M., Ermold, W., Häkkinen, S., Holland, D., Holloway, G., Karcher, M., Kauker, F., Maslowski, W., Steiner, N., Zhang, J., 2001a. Adrift in the Beaufort Gyre: a model intercomparison. Geophysical Research Letters 28 (15), $2835-2838$.

Steele, M., Moreley, R., Ermold, W., 2001b. PHC: a global ocean hydrography with a high quality Arctic Ocean. Journal of Climate 14, 2079-2087.

Steiner, N., Holloway, G., Sou, T., 2003. Estimation of Arctic windspeeds and stresses with impacts on ocean-ice snow modeling. Journal of Marine Systems 39, 129-151.

Swift, J., Jones, E., Aagaard, K., Carmack, E., Hingston, M., Macdonald, R., McLaughlin, F., Perkin, R., 1997. Waters of the Makarov and Canada Basins. Deep Sea Research II (44), 3371-3382.

Willebrand, J., Barnier, B., Böning, C., Dieterich, C., Killworth, P., LeProvost, C., Yia, J., Molines, J.-M., New, A., 2001. Circulation characteristics in three eddy-permitting models of the North Atlantic. Progress in Oceanography 48 (2-3), 123-161.

Woodgate, R.A., Aagaard, K., Muench, R.D., Gunn, J., Björk, G., Rudels, B., Roach, A., Schauer, U., 2001. The Arctic Ocean boundary current along the Eurasian slope and the adjacent Lomonosov Ridge: water mass properties, transports and transformations from moored instruments. Deep Sea Research I (48), 1757-1792.

Zhang, J., Rothrock, D., Steele, M., 2000. Recent changes in Arctic sea ice: the interplay between ice dynamics and thermodynamics. Journal of Climate 13, 3099-3114. 